\title{
The Influence of Human Relations and Communication on Employee Performance Through Work Ethics in Gowa Regency
}

\author{
Herlinah, Buyung Ramadhoni, Mansur Azis \\ Sekolah Tinggi Ilmu Ekonomi AMKOP Makassar, Indonesia \\ herlina@gmail.com, Buyung@gmail.com,mansur_asiz@stieamkop.ac.id \\ Miandhani Denniz Yuniar \\ Universitas Selamat Sri, Kendal, Indonesia \\ mdenniz@gmail.com \\ Yusriadi Yusriadi \\ Sekolah Tinggi Ilmu Administrasi Puangrimaggalatung, Makassar, Indonesia \\ yusriadi.yusriadi@uqconnect.edu.au \\ Minarti Usman \\ Baubau Islamic School of Religion (STAI). \\ minarti393@gmail.com \\ Dwi Lindarto Hadinugroho \\ Departemen Arsitektur, Fakultas Teknik, Universitas Sumatera Utara \\ dwi.lindarto@usu.ac.id
}

\begin{abstract}
The purpose of this study was to determine and analyze whether human relations and communication have a positive and significant effect on employee performance through work ethic in Gowa Regency (review at the Pallangga, Bajeng, and Bontonompo sub-district offices). This type of research is explanatory research. Sampling was used in the census method with a sample of 91 respondents. Distributing questionnaires to respondents was as collecting data. Furthermore, the whole data is processed using SPSS 16.0 software. The results showed, (1). Human relations have a positive and significant effect on work ethic in Gowa Regency: (2). Communication has a positive and significant impact on work ethic in Gowa Regency; (3). Human relations have a positive and significant impact on performance in Gowa Regency: (4). Work Communication has a positive and significant impact on performance in Gowa Regency; (5). Work ethic has a positive and significant impact on performance in Gowa Regency; (6). Human relations have a positive and insignificant influence on performance through work ethic in Gowa Regency; (7). Communication has a positive and significant impact on performance through work ethic in Gowa Regency
\end{abstract}

Keywords:

Human Relations, Communication, Work Ethic, Performance

Biographies

Herlinah is a student at Magister Program of Economic Science of STIE AMKOP, Indonesia. Her areas of interest and research include social science and economic. She has published some articles in national journals.

Buyung Ramadhoni is a lecturer at Economics Department of STIE AMKOP, Indonesia. His areas of interest and research include economic, management, management human resource. He has published some books and many articles in national and international journals. 
Mansur Azis is a lecturer at Economics Department of STIE AMKOP, Indonesia. His areas of interest and research include economic, management, management human resource. He has published some books and many articles in national and international journals.

Miandhani Denniz Yuniar is lecturer in the Department of Communication at Selamat Sri University, Indonesia. Her research areas and interests include communication science in marketing, digital media, advertising, and promotion. As a lecturer, she has published several scientific articles in national journals. She is also active in the PERHUMAS Semarang organization

Yusriadi Yusriadi is a lecturer at Public Administration Department of Sekolah Tinggi Ilmu Administrasi Puangrimaggalatung, Indonesia and chancellor on Sekolah Tinggi Ilmu Hukum Pengayoman. His areas of interest and research include social science, political science, sociology, legal studies, and public administration. He has published some books and many articles in national and international journals. He is a reviewer and editor in some local and international journals.

Minarti Usman, $\mathrm{He}$ is a lecturer at the YPIQ Baubau Islamic School of Religion (STAI). Undergraduate education, namely in the Physics Education study program, Faculty of Mathematics and Natural Sciences, Makassar State University and S2 focus on Educational Research and Evaluation, Makassar State University Postgraduate Program. Currently, he is actively publishing his work in national journals.

Dwi Lindarto Hadinugroho is a lecturer at the Department of Architecture, Faculty of Engineering, University of North Sumatra, Indonesia. currently still active in the process of teaching and research. 